Ks. Marcin WYSOCKI*

\title{
IDEAL MĘDRCA W LISTACH ŚW. AMBROŻEGO
}

Ambroży z Mediolanu jako duszpasterz i kaznodzieja, zatroskany o rozwój powierzonych jego pieczy wiernych, w swych wypowiedziach przedstawiał program rozwoju duchowego, moralnego i intelektualnego. Ukazywał więc ideał świętości doskonałego chrześcijanina, najlepszego chrześcijańskiego władcy ${ }^{1}$, wzorowego kapłana i biskupa ${ }^{2}$, ale także - wpisując się w antyczne poszukiwania doskonałego człowieka - przedstawił chrześcijański ideał mędrca, postulowany przez różne filozoficzne szkoły i prądy. W niniejszym artykule zostanie zatem ukazany ideał mędrca zaprezentowany przez Biskupa Mediolanu w jego korespondencji. Poszukiwania takiego modelu właśnie w listach Ambrożego są tym bardziej właściwe, że do tej pory temat ten nie został poruszony w badaniach nad twórczością biskupa.

1. „Roztrząsane i dyskutowane w rozprawach filozofów”. W liście 7. skierowanym do Symplicjana, który był duchowym ojcem biskupa i odbiorca kilku listownych komentarzy biblijnych ${ }^{3}$, Ambroży, analizując zdanie apostoła Pawła z Pierwszego Listu do Koryntian: „Za wielką cenę zostaliście nabyci. Nie bądźcie więc niewolnikami ludzi!" $(7,23)$, wskazuje od razu na zagadnienie cech mędrca oraz na filozoficzny kontekst tych rozważań i stwierdza:

„To zdanie było z wielkim wysiłkiem roztrząsane i dyskutowane w rozprawach filozofów, twierdzących, że «każdy mędrzec jest wolny», każdy zaś głupiec niewolnikiem"'.

* Ks. dr Marcin Wysocki - adiunkt w Katedrze Patrologii Greckiej i Łacińskiej w Instytucie Historii Kościoła i Patrologii na Wydziale Teologii Katolickiego Uniwersytetu Lubelskiego Jana Pawła II; e-mail: mwysocki@kul.lublin.pl.

${ }^{1}$ Por. M. Wysocki, Obraz chrześcijańskiego władcy w listach św. Ambrożego, VoxP 61 (2014) 171-177.

${ }^{2}$ Por. tenże, Radości i troski biskupiego życia z perspektywy listów św. Ambrożego, Biskupa Mediolanu, w: Veritas Christi Liberat. Księga Pamiqtkowa ku czci Księdza Biskupa Jacka Jezierskiego w 65. rocznicę urodzin, 40. rocznicę kapłaństwa i 20. rocznicę biskupstwa, red. K. Parzych-Blakiewicz - P. Rabczyński - J.M. Wojtkowski, Olsztyn 2014, 725-740.

${ }^{3}$ Por. J. Naumowicz, Wstęp, w: Św. Ambroży z Mediolanu, Listy, thum. P. Nowak, t. 1, BOK 9 , Kraków 1997, 21.

${ }^{4}$ Ambrosius, Epistula 7, 4, SAEMO 19, ed. G. Banterle, Milano - Roma 1988, 74: „Quae sententia magno a philosophis fluctuata atque iactata est disputationis molimine dicentibus quia «omnis 
Ambroży nie podaje źródła tego stwierdzenia, jednak łatwo rozpoznać, że odwołuje się on do nauczania najbardziej wówczas rozpowszechnionego nurtu filozoficznego, jakim był stoicyzm. Jednak idea mędrca nie była oryginalnym wytworem wyłącznie szkoły stoickiej, lecz była obecna również w innych systemach filozoficznych. W pierwotnej kulturze greckiej - przed śmiercią Sokratesa w 399 prz. Chr. - mędrcem określano człowieka posiadającego wyjątkowe talenty lub życiową wiedzę i mądrość, często bardzo praktyczną jak np. tworzenie poezji, zdolności polityczne. Takie jednostki były obiektem podziwu, ale i podejrzeń wśród zwykłych ludzi i często swoistego wykluczenia ${ }^{5}$. Mentalna zmiana związana z ruchem sofistycznym, która dokonała się w V w. prz. Chr., stworzyła mędrca, który znajdował się nie poza społeczeństwem, ale był częścią edukacyjnego procesu w państwie. Ideałem mędrca stał się filozof - posiadacz wiedzy o prawdzie, przede wszystkim o prawdzie etycznej, o sposobie postępowania godnym istot ludzkich, o prawdzie opartej na platońskiej teorii idei. Mędrcem stał się filozof jako całkowicie racjonalny myśliciel ${ }^{6}$. Dla Epikura i epikurejczyków mędrcem był człowiek, który rozumem przezwycięża nienawiść, zazdrość i pogardę. Jest on zawsze szczęśliwy i wdzięczny. Nie powinien się żenić i posiadać dzieci ani zajmować się polityką, ani dążyć do władzy królewskiej. Epikurejski mędrzec lubi życie wiejskie i uroczystości świąteczne ${ }^{7}$. Sceptycy, negujący możliwość poznania i wiedzy, konsekwentnie zaprzeczali możliwości istnienia mędrca. Osoba taka, jeżeliby istniała, byłaby mędrcem z powodu właśnie powszechnej negacji wszystkiego i praktykowania doskonałej દ̇ $\pi \mathrm{o} \chi \eta^{8}$. Dla perypatetyków mędrcem był człowiek kontemplujący niezmienne prawdy, dla pitagorejczyków - człowiek wyznający zasady filozofii pitagorejskiej: teorię liczb, astronomię, metempsychozę. Cynicy, którzy nie byli związani z żadnym konkretnym systemem filozoficznym, w ideale mędrca ponad wszystko akcentowali pewien sposób życia bez materialnego zabezpieczenia, ale za to przedkładając ponad wszystko czystość elementu racjonalnego i władczego $\mathrm{w}$ duszy oraz praktyczne działanie ${ }^{9}$.

Ambroży, jak wskazano powyżej, odwołuje się jednak do konkretnej wypowiedzi, przywołując anonimowo prawdopodobnie słowa Zenona z Kition ${ }^{10}$. Nie jest to zresztą dziwne, skoro stoicka doktryna dotycząca mędrca była szeroko rozpowszechniona i wpływała na kształtowanie się ideału mędrca w innych szkołach filozoficznych. Model mędrca jest szczytowym punktem

sapiens liber», omnis autem insipiens serviat”, tłum. P. Nowak: Św. Ambroży z Mediolanu, Listy, BOK 9, 68.

${ }^{5}$ Por. G.B. Kerferd, The Sage in Hellenistic Philosophical Literature, w: The Sage in Israel and the Ancient Near East, ed. J.G. Gammie - L.G. Perdue, Winona Lake 1990, 319.

${ }^{6}$ Por. tamże, s. 320.

${ }^{7}$ Por. Diogenes Laertios, Vitae philosophorum 10, 117-121b; Kerferd, The Sage, s. 322-324.

${ }^{8}$ Por. Sextus Emipricus, Adversus mathematicos 7, 156-157; Kerferd, The Sage, s. 324-325.

${ }^{9}$ Por. Kerferd, The Sage, s. 325-326.

${ }^{10}$ Por. Diogenes Laertios, Vitae philosophorum 7, 121-122. 
etyki stoickiej, ale wypływa z całego systemu filozoficznego tej szkoły, bazującego na dualizmie, materializmie i racjonalności. Podstawą etyki stoickiej było przekonanie o łączności szczęścia i cnoty. Aby zapewnić sobie szczęście trzeba uniezależnić się od zewnętrznych okoliczności, zapanować nad sobą, stać się wolnym, zapanować rozumem nad materią i wyrzec się wszystkiego, aby posiąść dobra wewnętrzne, wśród których na pierwszym miejscu znajduje się cnota - największa doskonałość i jedyne prawdziwe dobro - będąca życiem zgodnym z naturą. Kto działa zgodnie ze swoją natura, ten jest wolny i prowadzi życie cnotliwe. Życie zgodne $z$ naturą jest jednocześnie zgodne z rozumem, który stanowi naturę człowieka i który rządzi nie tylko człowiekiem, ale i całym kosmosem. W tak pojętym systemie, mędrcem jest ten, kto jest rozumny i cnotliwy, a przez to szczęśliwy, wolny, bogaty, bo posiadający to, co najcenniejsze ${ }^{11}$. Jest więc mędrzec bogaty, szlachetny i piękny, nawet jeżeli nic nie posiada, jeżeli jest niewolnikiem i brzydkim, ponieważ jest człowiekiem doskonałym, żyjącym w całkowitej harmonii z rozumem, kierujący się nim w swoich czynach, a więc jest jedynym podejmującym właściwe decyzje i czyny, posiadającym wiedzę ${ }^{12}$. Mędrzec według stoików jest wolny, ponieważ chce tego wszystkiego, co jest konieczne; znosi i przyjmuje wszystko, czego chce fatum ${ }^{13}$. Stoik, mędrzec odznacza się obojętnością uczuciową i wolnością od namiętności, a więc także od litości, współczucia czy miłosierdzia $^{14}$. Według stoików osiagnięcie tych wszystkich cech jest prawie niemożliwe, dlatego też stwierdzano, że do tej pory nie znaleziono na świecie mędrca ${ }^{15}$.

2. „Szukajmy więc czlowieka prawdziwie mądrego, prawdziwie wolnego" ${ }^{16}$. Ambroży wpisuje się tymi słowami w nurt stoickich poszukiwań mędrca. Nie rozstrzyga jeszcze czy możliwe jest, czy też nie, znalezienie mędrca wśród ludzi. Wskazuje jednak na kierunek poszukiwań, zbieżny z poszukiwaniami stoików: mędrzec to człowiek wolny.

${ }^{11}$ Por. W. Tatarkiewicz, Historia filozofii, t. 1: Filozofia starożytna i średniowieczna, Warszawa 1993, 132-134. Zob. R. Brouwer, The Stoic Sage: The Early Stoics on Wisdom, Sagehood and Socrates, Cambridge 2014; M.M. McCabe, The Stoic Sage in the Original Position, w: Politeia in Greek and Roman Philosophy, ed. V. Harte - M. Lane, Cambridge 2013, 251-274.

${ }^{12}$ Por. Kerferd, The Sage, s. 321-322. Zob. G.B. Kerferd, What Does the Wise Man Know?, w: The Stoics, ed. J.M. Rist, Berkeley - Los Angeles - London 1978, 125-135.

${ }^{13}$ Por. G. Reale, Historia filozofii starożytnej, tłum. E.I. Zieliński, t. 3: Systemy epoki hellenistycznej, Lublin 1999, 432-433. Na temat stoickiego pojęcia wolności zob. S. Bobzien, Stoic conceptions of freedom and their relation to ethics, w: Aristotle and After, ed. R. Sorabji, Bulletin of Institute of Classical Studies, Suppl. 68, London 1997, 71-89.

${ }^{14}$ Por. Reale, Historia filozofii starożytnej, t. 3, s. 435; J. Ammas, The Sage in Ancient Philosophy, w: Anthropine Sophia. Volume in memory of Gabriele Giannantoni, ed. F. Alesse, Naples 2008, 17.

${ }^{15}$ Por. Brouwer, The Stoic Sage, s. 92-93 i 97-112.

${ }^{16}$ Ambrosius, Epistula 7, 30, SAEMO 19, 88, BOK 9, 77. 
We wspomnianym już liście 7., skierowanym do Symplicjana ${ }^{17}$, biskup Mediolanu wyjaśnia fragment Pierwszego Listu św. Pawła do Koryntian $(7,23)^{18}$ i na jego podstawie wyprowadza wnioski dotyczące tego, kto jest mędrcem. Zatem punktem wyjścia rozważań jest tekst biblijny, zaraz jednakże wskazuje biskup na powiedzenie filozoficzne powiązane ze szkołą stoicka, następnie jednak powraca do myśli biblijnej, która dotyczy zagadnienia wolności i mądrości, przywołując znaną i popularną teorię kradzieży i wcześniejszego istnienia myśli biblijnej od filozofów greckich. Ambroży ukazuje zatem, że już wcześniej myśl o tym, że mędrzec jest wolny, a głupi jest niewolnikiem, była obecna w świecie judaistycznym. Wprost mówi Ambroży, że filozofia zaczerpnęła z mądrości i wiedzy ojców, i wskazuje na Salomona, Noego, Jakuba, Józefa, którzy ukazują w swym życiu współzależność wolności i mądrości ${ }^{19}$. Przy okazji jednak biskup Mediolanu przeprowadza wykład dotyczący tej zależności, w znacznym stopniu opierając się na dziele Quod omnis probus liber sit Filona Aleksandryjskiego. Ukazuje kwestię wolności, wskazuje na niewolników, którzy rządzili innymi, podejmowali trafne i ważne decyzje i w związku z tym Ambroży zdaje się zadawać pytanie: kto w takim razie naprawdę jest wolny? I w tym kontekście wskazuje na mędrca, który jest naprawdę wolny:

„Wolność nie polega na dobroczynności, lecz jest cnotą; nie udziela się jej przez głosy innych, lecz dochodzi się do niej i posiada ją przez własną wielkość ducha. Mędrzec bowiem zawsze jest wolny, zawsze poważany, zawsze jest tym, który może kierować prawami" ${ }^{20}$.

${ }^{17}$ Warte podkreślenia jest to, że właśnie w listach do swego duchowego ojca Ambroży porusza najczęściej kwestie mądrości (por. tamże $2 ; 3 ; 7 ; 10$ ). Z pewnością dla Ambrożego to właśnie Symplicjan, jako nauczyciel i przewodnik w okresie przygotowania do chrztu i biskupstwa, był wzorem mędrca. Choć Ambroży nigdy dosłownie o tym nie mówi, zdają się na to wskazywać chociażby słowa z początku listu 2., gdzie ukazuje zaangażowanie kapłana w zdobywanie wiedzy i wiary; por. tamże 2,1 .

${ }^{18}$ Powszechnie wskazuje się na zależność myśli Pawła Apostoła od poglądów stoickich, por. M. Pohlenz, Paulus und die Stoa, ZNW 42 (1949) 69-104; J.N. Sevenster, Paul and Seneca, Supplements to „Novum Testamentum” 4, Leiden 1961; T. Engberg-Pedersen, Paul and the Stoics, Louisville 2000; R.J. Gibson, Paul and the Evangelization of the Stoics, w: The Gospel to the Nations: Perspectives on Paul's Mission, ed. P. Bolt - M. Thompson, Downers Grove 2000, 309-326; R.M. Thorsteinsson, Stoicism as a Key to Pauline Ethics in Romans, w: Stoicism in Early Christianity, ed. T. Rasimus - T. Engberg-Pedersen - I. Dunderberg, Grand Rapids 2010, 15-38; N. Huttunen, Stoic Law in Paul?, w: Stoicism in Early Christianity, ed. T. Rasimus - T. Engberg-Pedersen - I. Dunderberg, Grand Rapids 2010, 39-58. Istnieje także apokryficzna tradycja wymiany listów pomiędzy św. Pawłem a Seneką, por. K. Obrycki, Apokryficzna korespondencja pomiędzy Senekq i świętym Pawtem, WST 10 (1997) 219-240.

${ }^{19}$ Por. Ambrosius, Epistula 7, 5-11.

${ }^{20}$ Tamże 7, 18, SAEMO 19, 80: „Non enim munificientiam, sed virtutem libertatem esse arbitror, quae non suffragiis defertur alienis, sed magnanimitate propria vindicatur ac possidetur. Sapiens enim semper liber, semper honoratus, semper is qui praesit legibus", BOK 9, 73. 
Następnie przechodzi biskup do pogłębienia tej myśli. Według niego mędrzec jest wolny, ponieważ robi to, co chce. Jednak Ambroży ogranicza tę całkowitą wolność - mędrzec robi tylko to, co dobre, chce tylko dobra, ,nienawidzi zła, gdyż wybrał to, co jest dobre"21. Wybierając dobro stał się wolny w działaniu. Zatem cechą działania mędrca jest wolność i dobro. Mędrzec wszystko czyni dobrze, a zatem właściwie, a w konsekwencji bez przeszkód, bez szkody i bez wzburzenia. Widać więc, że Ambroży postępuje za ideami stoickimi apathei, spokoju i równowagi. Wskazuje, że kto tak postępuje, postępuje roztropnie, a jeżeli postępuje roztropnie, nie boi się grzechu, nie boi się niczego, a ponieważ nie ma obaw, więc jest wolny ${ }^{22}$. Mędrzec jest wolny, ponieważ nie można go zmusić do niczego ani od niczego powstrzymać, ponieważ pragnie dobra, cnoty i dyscypliny, które czynią go prawdziwym i czynią go sobą. W sposób wolny oddaje się on cnocie i ją praktykuje. Pisząc o wolności i o cnocie Ambroży używa oczywiście terminologii stoickiej, wprost niemal przywołując stwierdzenia stoików:

„We wszystkich zaś działaniach są zawarte albo dobre uczynki, pochodzące z napomnień dawanych przez cnote, albo upadki spowodowane przez nieprawość, albo czyny pośrednie i moralnie obojętne"²3.

Mędrzec, według Ambrożego, wolny jest od nieprawości, jest stały w swoim oddaniu cnocie, nie skłania się ku przyjemnościom, jest niewzruszony w swym uczuciu, a zatem:

„mędrzec niczego nie robi wbrew swojej woli, ani nie jest przymuszony, ponieważ gdyby był niewolnikiem, byłby przymuszony. Wolny przeto jest mędrzec" 24 .

Wolność mędrca zasadza się zatem na wolności wyboru i wyborze dobra oraz cnoty. Ważne jest jednak również to, że mędrcowi „się chce” - chce się dokonywać wyborów, być wolnym, bowiem „chcenie jest cechą mędrca"25. Ambroży stosuje w swoim wywodzie szereg sylogizmów, które mają na celu logiczne ukazanie zależności pomiędzy wszystkimi elementami stanowiącymi mędrca i konstytuującymi jego postawę wobec cnoty, dobra i innych elementów przejętych z filozofii stoickiej. O ile jednak do tej pory to na niej opierał głównie Ambroży swoje rozważania, nie odnosząc się do Pisma Świętego i religii chrześcijańskiej, to $\mathrm{w}$ dalszych rozpatrywaniach powiązań pomiędzy

${ }^{21}$ Por. tamże 7, 19.

${ }^{22}$ Por. tamże.

${ }^{23}$ Tamże 7, 20, SAEMO 19, 82: „In omnibus autem factis aut a virtute correctiones sunt aut a malitia prolapsiones aut media et indifferentia", BOK 9, 74 .

${ }^{24}$ Tamże: ,nihil inuitus facit sapiens neque cogitur, quia si servus esset, cogeretur. Liber igitur est sapiens", BOK 9, 75.

${ }^{25}$ Tamże 7, 21, SAEMO 19, 84: „Velle ergo sapientis est”, BOK 9, 75. 
mądrością i wolnością sięga już do argumentów religijnych, tworząc na podbudowie stoickiej obraz mędrca chrześcijańskiego.

Jako przykład człowieka wolnego i mądrego daje Ambroży św. Pawła Apostoła, który sam stwierdza, że jest wolny (por. 1Kor 9, 1) i nie godzi się na ustępstwa, aby głosić Ewangelię (por. Ga 2, 4-5). Zgodnie więc z ukazanymi powyżej zasadami stoickimi Paweł jest wolny, gdyż chce głosić Ewangelię, a nie jest do tego przymuszony. Ten zaś, kto działa $\mathrm{z}$ własnej woli jest mędr$\mathrm{cem}^{26}$. Ewangelia wyzwala $\mathrm{z}$ niewoli Prawa i w niej jest:

„poznanie mądrości, wolność. Każdy więc, kto przyjmuje Chrystusa, jest mądry, kto zaś jest mądry, jest wolny; każdy więc chrześcijanin jest równocześnie i wolny, i mądry"27

konstatuje biskup, ukazując chrześcijanina jako mędrca. Chrześcijańskie pojęcie wolności, według Ambrożego, idzie jednak znacznie dalej. O ile wcześniej wykazał, że również niewolnik może być wolnym, to teraz ukazuje, że tak naprawdę chrześcijanin, który jest wolny, jest jednocześnie niewolnikiem. Niewola zaś ta jest niewolą miłości, służby, bowiem ,dla mędrca i służenie jest wolnością"28. Według Ambrożego zatem jedną z cech mędrca związaną z wolnością jest umiejętność stania się niewolnikiem Chrystusa, niewolnikiem miłości, niewolnikiem mądrości. Doskonałą bowiem wolnością i doskonałym zniesieniem niewoli jest życie w Chrystusie i niewola w wolności, którą symbolicznie biskup opisuje jako włożenie nogi w dyby mądrości (por. Syr $6,24)^{29}$. Każdy bowiem człowiek mądry i rozsądny wkłada nogi do jej dybów $^{30}$. Najdoskonalszą służbą jest oczywiście służba Bogu, niewola u Boga, który obdarza i oświeca umysł mądrością, i jest Ojcem i Rodzicielem mądrości $^{31}$. I dlatego Biskup stwierdza, że jedynie ten jest mądry, „kto doszedł aż do tajemnic bóstwa i poznał objawione sobie «tajniki mądrości» (Ps 51, 8)"32. Ten jest mądry, kto z Bożą pomocą poznał tajemnice prawdy, stał się nieśmiertelnym dziedzicem prawdy, następcą Boga i uczestnikiem Jego radości ${ }^{33}$.

Następnie Ambroży powraca do stoickich wyrażeń i koncepcji, i wskazuje - odwołując się znowu do dzieła Filona Aleksandryjskiego - że mędrca tworzy zwyciężanie:

${ }^{26}$ Por. tamże 7, 21.

${ }^{27}$ Tamże 7, 22, SAEMO 19, 84: ,in euangelio libertas, ubi cognitio sapientiae. Omnis ergo qui Christum recipit, sapiens, qui autem sapiens, liber; omnis igitur Christianus et liber et sapiens", BOK 9, 75.

${ }^{28}$ Tamże 7, 24, SAEMO 19, 86: „Est ergo sapienti et seruire libertas”, BOK 9, 76.

${ }^{29}$ Por. tamże $17,10$.

${ }^{30}$ Por. tamże 16, 10.

${ }^{31}$ Por. tamże 2, 4.

32 Tamże 7, 29, SAEMO 19, 86: „Quis igitur sapiens, nisi qui ad ipsa pervenit divinitatis secreta et manifestata sibi cognovit «occulta sapientiae»?", BOK 9, 77.

${ }^{33}$ Por. tamże. 
„,nad zmysłowością, strachem, lenistwem, smutkiem i pozostałymi wadami, które pokonał, i nad którymi zatriumfował" 34 .

Dodaje jednak natychmiast do tego katalogu przeciwności zawarte w Piśmie Świętym - śmierć, prześladowania - którym chrześcijanin, jako człowiek mądry i wolny, nie może się poddawać, lecz winien nad nimi panować i je zwyciężać ${ }^{35}$. Wprowadza tu Ambroży z jednej strony pojęcie grzesznika i z drugiej strony człowieka żyjącego według prawa. Grzesznik jest synonimem niewolnika, gdyż jest pełen obaw i pożądań, zaś człowiek żyjący według prawa to synonim mędrca i człowiek wolnego. Wydaje się w tym miejscu Ambroży nieco niekonsekwentny, gdyż wcześniej odrzucał Prawo jako siedlisko niewoli ${ }^{36}$, a jednocześnie wskazywał, że

„ten jest wolny, kto jest wolny w swoim wnętrzu, kto jest wolny według praw natury, wiedząc, że prawo natury jest nakazane obyczajom, i że miara obowiązków jest zgodna nie z osądem człowieka, lecz z porządkiem natury"37.

Ambroży próbuje pogodzić tu stanowisko stoików i nauczanie przede wszystkim Pawłowe poprzez wprowadzenie kategorii Prawa, jako prawa Starego Przymierza, któremu poddani byli Żydzi, oraz prawa naturalnego, które jest „odciśnięte w umysłach i wytłoczone w uczuciach” i utworzone na obraz Boży ${ }^{38}$. Mędrzec, jak wskazuje Ambroży w innym liście, przede wszystkim zna owo Boże Prawo, które zostało dane jako wychowawca, z powodu niestałego charakteru i słabego ducha ludzi, ale także pojmuje „myśl umysłu Bożego, której litera [Prawa] nie wyraziła"39 oraz zachowuje tajemnicę (mysterium), która zawiera się w Prawie ${ }^{40}$. Człowiek mądry nie może nadto być nieposłuszny prawu naturalnemu, zaniedbywać je i odrzucać, ponieważ pochodzi ono od Boga ${ }^{41}$. Jako przykłady ludzi mądrych Ambroży podaje króla

${ }^{34}$ Tamże 7, 30, SAEMO 19, 88: „Insurgit enim sapiens quasi victor debellatis a se ac triumphatis libidini, timori, ignaviae, maestitudini ceterisque vitiis", BOK 9, 77. Por. Philo Alexandrinus, Quod omnis probus liber sit 3, 21.

${ }^{35}$ Por. Ambrosius, Epistula 7, 31.

${ }^{36}$ Por. tamże 7, 22.

${ }^{37}$ Tamże 7, 17, SAEMO 19, 80: ,ille magis liber, qui intra se liber est, qui legibus naturae liber est, legem sciens naturae praescriptam esse moribus, non condicionibus, et mensuram officiorum consentaneam non hominis arbitrio, sed naturae disciplinis", BOK 9, 72.

${ }^{38}$ Tamże 7, 32, SAEMO 19, 88: ,,sed inpressa mentibus atque infixa sensibus [...] veram legem naturae expressam ad imaginem dei", BOK 9, 78-79.

${ }^{39}$ Tamże 64, 3, SAEMO 20, 176: ,sapiens intellegeret divinae mentis sententiam, quam littera non resonaret", BOK 9, 78-79.

${ }^{40}$ Por. tamże.

${ }^{41}$ Por. tamże 7, 32. 
Dawida $^{42}$, Hioba $^{43}$, Mojżesza ${ }^{44}$, męczennice: Teklę, Agnieszkę ${ }^{45}$ i Pelagię ${ }^{46}$. Ludzie ci są przykładem wolności, która przejawia się w stałości i mocy umysłu, charakteru, serca i czynów ${ }^{47}$; w pogardzie dla śmierci ${ }^{48}$; niezależności od gniewu, pragnień i przyjemności oraz ambicji ${ }^{49}$. Wolność taka przystoi tylko człowiekowi mądremu. Drogą do uzyskania i trwania w wolności jest wyznanie Panu win i grzechów oraz otrzymanie rozgrzeszenia ${ }^{50}$. W tym również przejawia się mądrość mędrca, bowiem

„mądry jest ten, kto wyznaje swoją winę, wolny ten, komu grzech został odpuszczony, bo nie wlecze za sobą żadnych długów grzechu"s1.

W liście 3. skierowanym również do Symplicjana, Ambroży podejmuje tę samą myśl, co więcej wpisuje się w stoicki pesymizm odnośnie do możliwości istnienia mędrca. Stwierdza, że jedynie Bóg nigdy nie grzeszy, zaś „,cechą mędrca jest to, że stara się poprawić, naprawić swój błąd i czynić pokutę za grzech" "52. Jednak, jak zauważa biskup, ludziom w tym życiu przychodzi to bardzo trudno ${ }^{53}$ i nawiązuje tym samym do tej teorii stoickiej mówiącej o niemożliwości osiągnięcia w tym życiu statusu mędrca ${ }^{54}$. Przyczyną takiego stanu rzeczy - rzadkiego wyznawania grzechów, rzadkiej skruchy - jest, jak wskazuje Ambroży, sprzeciw natury i wstyd ${ }^{55}$. Jednak Ambroży znajduje wyjście z tej tragicznej dla człowieka sytuacji braku mądrości i niewłaściwego „spalenia” grzechów ${ }^{56}$. Ostatecznie to Bóg przecież wlewa w czary ludzkich umysłów i zmysłów krew mądrości ${ }^{57}$, początkiem mądrości zawsze jest jednak ofiara z krwi wylana na ołtarz, czyli obmycie z grzechów, jak tłumaczy Ambroży komentując fragment Księgi Wyjścia o podziale krwi z ofiar (por.

${ }^{42}$ Por. tamże 7, 25.

${ }^{43}$ Por. tamże 7, 27-28.

${ }^{44}$ Por. tamże 7, 33.

${ }^{45}$ Por. tamże 7, 36.

${ }^{46}$ Por. tamże 7, 32; 7, 38.

${ }^{47}$ Por. tamże 7, 33.

${ }^{48}$ Por. tamże 7, 33. 35-38.

${ }^{49}$ Por. tamże 7, 39.

${ }^{50}$ Por. tamże 7, 45.

${ }^{51}$ Tamże 7, 45, SAEMO 19, 88: „Sapiens est igitur qui confietur, liber cui peccatum dimissum est nulla iam trahens aera peccati”, BOK 9,84 .

${ }^{52}$ Tamże 3, 4, SAEMO 19, 44: „Nihil peccare solius est dei, emendere sapientis est et corrigere erratum et paenitentiam gerere peccati”, BOK 9, 45 .

${ }^{53}$ Por. tamże 3, 4 .

${ }^{54}$ Por. nota 15.

${ }^{55}$ Por. Ambrosius, Epistula 3, 4.

${ }^{56}$ Por. tamże 3, 7-8. Nasuwa się tu wyraźne skojarzenie z „wszystko trawiącym” ogniem stoickim, który pozwala duszy powrócić do stanu pierwotnej doskonałości.

${ }^{57}$ Por. tamże 2, 4-6. 
$\mathrm{Wj} 24,6)^{58}$. Ogniem spalającym grzechy, przywracającym do stanu posiadania mądrości, do stanu mędrca, jest ostatecznie Duch Święty, który obmywa winy i gładzi grzechy ${ }^{59}$.

3. „Mądremu także nic nie jest obce" ${ }^{60}$. Jednak nie tylko wolność jest cechą mędrca. W swoich listach biskup Ambroży przedstawia całe spektrum różnych cech, którymi odznacza się mędrzec. Co ciekawe na temat wszystkich cech biskup pisze jako o obecnych w mędrcu, a nie jako o powinności i malowaniu obrazu doskonałego mędrca w teorii. Ambrozjańskiemu mędrcowi rzeczywiście nic nie jest obce ,Z wyjątkiem tego, co nie jest odpowiednie dla cnoty” ${ }^{61}$.

W liście 10., skierowanym również do kapłana Symplicjana, w którym Ambroży nawiązuje do ukazanych powyżej, przeprowadzonych w liście 7 . rozważań na temat najważniejszej cechy mędrca, wskazuje także, że jest nią nie tylko wolność, ale także bogactwo, które nie jest bogactwem materialnym, ale bogactwem serca. Ambroży, interpretując słowa św. Piotra (por. 1P 3, 3-4), rozszerza to wyjątkowe bogactwo ukryte w sercu na wszystkich ludzi, bez względu na płeć ${ }^{62}$. W myśli Ambrożego to właśnie to bogactwo serca, ów ,wewnętrzny człowiek serca" (interior cordis homo), jest synonimem mądrości:

„dlatego, że będąc cały oddany mądrości, jest ukryty, tak jak sama mądrość, której się nie widzi, lecz się ją pojmuje" ${ }^{63}$.

Ów wewnętrzny człowiek jest cały oddany mądrości, jest pełen łaski i majestatu, niezmiennego spokojnego i skromnego ducha, który jest bogaty przed Bogiem $^{64}$. Człowiek serca posiada więc wszystkie przymioty mędrca, dlatego też jest człowiekiem bogatym, a w świecie nie istnieje nic bogatszego nad usposobienie mędrca ${ }^{65}$. W swych dalszych rozważaniach nad człowiekiem bogatym-biedakiem, czyli mędrcem, Ambroży wyraźnie nawiązuje do stoickiej etyki, gdy wyjaśnia, na czym polega usposobienie mędrca i że bogatym jest:

„ten, kto ma pokój ducha, spokój wyciszenia, tak, że niczego nie pożąda, nie dręczą go żadne burze pożądliwości, nie czuje wstrętu do rzeczy starych ani nie szuka nowych i nie pożąda ciagle, będąc w ten sposób biedny pośród największych bogactw"66.

${ }^{58}$ Por. tamże 2, 10.

${ }^{59}$ Por. tamże 3, 9.

${ }^{60}$ Tamże 36, 11, SAEMO 20, 28: „Sapienti quoque nihil alienum”, thum. P. Nowak: Św. Ambroży z Mediolanu, Listy, t. 2, BOK 22, Kraków 2003, 11.

${ }^{61}$ Por. tamże: „nisi quod virtuti incongruum”.

${ }^{62}$ Por. tamże $10,1$.

${ }^{63}$ Tamże 10, 2, SAEMO 19, 108: „eo quod totus sapientiae sit absconditus sicut ipsa sapientia, quae non videtur, sed intellegitur", BOK 9, 91.

${ }^{64}$ Por. tamże 10, 2-3.

${ }^{65}$ Por. tamże 10, 10.

${ }^{66}$ Tamże, 10, 3, SAEMO 19, 108: „qui habet pacem animi, tranquillitatem quietis, ut nihil 
O takiej postawie - skupienia się na rzeczach duchowych, a nie materialnych, gdy serce, dzieła i czyny mędrca są zakorzenione i nieruchome zgodnie z etyką stoicką - pisał Ambroży interpretując wzniesienie i podpieranie przez Jozuego rąk Mojżesza. Mędrzec posiada ręce wzniesione, wyciagnięte od siebie, kiedy nie robi rzeczy powierzchownych, lecz tylko pełne doniosłości i cnoty, nie pod wpływem chwiejnego ducha i niepewnych uczuć, lecz w stałości umocnionego umysłu ${ }^{67}$. Niejako kontynuując temat gestów rąk i ciała w liście 27. Ambroży wskazuje, że mędrzec wznosi swe ręce, czyli porzuca sprawy cielesne i wznosi się do łaski zmartwychwstania ${ }^{68}$. Ze stosunkiem do świata dóbr materialnych łączy się także szczególna wiedza, którą posiada mędrzec. Wie on bowiem, że nagroda za zasługi na tej ziemi nie jest oceniana według marności dóbr doczesnych i że los i dzieje człowieka są zmienne. Używa przy tym biskup prostego, lecz wymownego porównania:

„Któryż bowiem mędrzec nie wie, że dzieje ludzkich spraw są jakby umieszczone na kręcącym się kręgu, gdyż nie mają zawsze tych samych pomyślnych wyników, lecz zmieniają swój stan i koleje losu?" 69

Dla biskupa Ambrożego rzeczywistość duchowa jest, co oczywiste, szczególnie ważna. Dlatego też również w kontekście mędrca i jego cech pojawia się ona nieustannie. Mądrość, która jest manną duchową, deszczem duchowym, dawana jest mędrcom - ludziom niezwykłym - ona bowiem żywi duszę mędrca, oświeca go i osładza. Rozlewana jest ona z nieba na ludzi inteligentnych, poszukujących jej, pobożnych. Ludzie obdarzeni nią i umiejący ją dostrzec, co wydaje się szczególną cechą mędrca w kontekście dotychczasowych rozważań, rozkoszują się nią i nie szukają innego pokarmu ${ }^{70}$. Poznanie i doświadczenie takiej mądrości, z której wypływa wolnośćc ${ }^{71}$, skutkuje tym, że:

„mędrca nie załamuje trwoga, nie zmienia władza, nie wywyższa powodzenie, nie pogrążają rzeczy smutne. Gdzie bowiem jest mądrość, tam jest cnota ducha, tam wytrwałość, tam męstwo. Mędrzec zatem pozostaje w duchu taki sam, nie umniejsza się ani nie wzrasta poprzez zmiany stanu rzeczy, ani nie waha się jak dziecko, tak iż byłby unoszony przez «każdy powiew nauki» (Ef 4, 14), lecz pozostaje doskonały w Chrystusie, utwierdzony przez miłość,

concupiscat, nullis exagitetur cupiditatum procellis nec vetera fastidiat et nova quaerat et semper desiderando fiat in summis diuitiis inops", BOK 9, 92.

${ }^{67}$ Por. tamże 7, 33.

${ }^{68}$ Por. tamże 27, 8.

${ }^{69}$ Tamże 73, 34, SAEMO 21, 82: „Quis enim sapiens non in orbe quodam atque circuitu locata humanarum rerum novit negotia, quia non eosdem sempre successus habent sed variant status et mutuant vices?", tłum. P. Nowak: Ambroży z Mediolanu, Listy, t. 3, BOK 28, Kraków 2012, 52.

${ }^{70}$ Por. tamże 54, 2.

${ }^{71}$ Por. tamże $7,4$. 
zakorzeniony przez wiarę. Mędrzec zatem nie zna braków rzeczy i nie umie być zmienny duchem"72.

Skoro mędrzec nie czuje przywiązania do rzeczy materialnych i nie poruszają go zmiany, a jednocześnie nic nie jest mu obce, to również odniesienie do miejsc i przestrzeni geograficznej jest wyjątkowe - mądry dokądkolwiek się uda, ma wszystko, cały świat jest jego posiadłością ${ }^{73}$. Omawiając w liście 34 ., w oparciu o zasady stoickie, dzieje stworzenia, Ambroży wyraźnie to podkreśla:

„Najpierw więc Bóg stworzył świat, a następnie mieszkańca świata, dla którego cały świat miał stać się ojczyzną. Bo jeśli dzisiaj mędrzec, dokądkolwiek by poszedł, wszędzie jest obywatelem, wszędzie rozpoznaje swoje rzeczy, nigdzie nie czuje się przybyszem, nigdzie nie uważa się za gościa, to o ileż bardziej ów pierwszy człowiek był mieszkańcem całego świata i - jak mówią Grecy - kosmopolita, ostatnim dziełem Boga"74.

Inną cechą mędrca, którą podkreśla św. Ambroży w swoich listach, jest mądrość wyrażająca się w języku i mowie. Dokonując w liście 31. interpretacji liczb związanych z sześcioma dniami stworzenia i powiązanych z tym liczb siedem i osiem, przedstawia także, znany w starożytności, podział wieku ludzkiego na poszczególne okresy. Według biskupa przedostatnia, dziewiąta hebdomada, odznacza się subtelnością w języku i mądrości ${ }^{75}$. Pomimo, że dopiero końcówce życia przypisał Ambroży ukształtowanie języka i mądrości, to jednak tak naprawdę każdy etap życia mędrca powinien charakteryzować się odpowiednim językiem i mądrością. Na przykład w liście do Konstancjusza, tuż po jego wyborze na biskupa, Ambroży udziela mu szeregu rad związanych z pracą duszpasterską, a szczególną uwagę zwraca właśnie na język, jakiego używa biskup w swej posłudze. Przywołując zdanie z Księgi Koheleta - „Słowa mędrców są jak ościenie" $(12,11)$ - zachęca młodego biskupa, aby jego słowa pobudzały słuchającego i doprowadzały do skruchy człowieka świadomego winy $^{76}$. Ponieważ wargi mądrego są bronią rozumu (por. Prz 14, 3), to mowa biskupa ma być pełna treści, sensu, jego kazania mają być jasne, a umysł błyskotliwy ${ }^{77}$. Niejako zachęcając, aby nowy biskup stawał się mędrcem w słowach i czynach Ambroży przypomina Konstancjuszowi:

${ }^{72}$ Tamże 7, 5, SAEMO 19, 108: ,qui habet pacem animi, tranquillitatem quietis, ut nihil concupiscat, nullis exagitetur cupiditatum procellis nec vetera fastidiat et nova quaerat et semper desiderando fiat in summis divitiis inops", BOK 9, 68.

${ }^{73}$ Por. tamże 36, 11.

${ }^{74}$ Tamże 34, 16, SAEMO 19, 326: „Nam si hodie quocumque accesserit sapiens, ubique civis est, ubique sua intellegit, nusquam se peregrinum, nusquam hospitem iudicat, quanto magis ille pri-

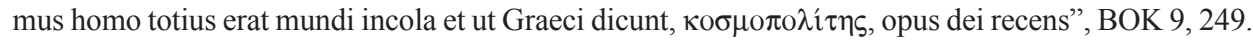

${ }^{75}$ Por. tamże $31,13$.

${ }^{76}$ Por. tamże 36, 5.

${ }^{77}$ Por. tamże 36, 7. 
„Twoje przemówienia i traktaty niech nie potrzebują innego potwierdzenia, lecz mowa twoja niech broni sama siebie jakby swoją własną bronią; i niech nie wychodzi z twoich ust żadne słowo na próżno i pozbawione znaczenia. [...] względem tych, którzy są dręczeni ciężkim poranieniem, używaj oliwy słów, aby nią złagodzić zatwardziałość ducha, przyłóż okład, dołącz przepaskę zbawiennego nakazu, abyś w żaden sposób przez twoją opieszałość i osłabioną gorliwość, gdy chodzi o wiarę i zachowanie dyscypliny, nie pozwolił zginąć niestałym i chwiejnym"78.

Również jako swoista przestroga i ukazanie anty-mędrca brzmią słowa biskupa Mediolanu z jego listu do cesarza Walentyniana. Podkreśla w nich Ambroży, że należy przede wszystkim zwracać uwagę na przekonującą moc faktów, czyli czyny, a nie na elegancję wymowy, co możemy dostrzec w powyższych wypowiedziach, ale nade wszystko biskup wskazuje, że istnieje język mądrych literatów, który tak naprawdę nie ma nic wspólnego z mądrością i językiem, jakim powinien posługiwać się prawdziwy mędrzec. Język owych mądrych literatów

,jest wyposażony w ozdobne mowy i jakby wybijając się olśniewającą wymową podobną do blasku mieniącej się barwy przyciąga oczy dusz powabnym kształtem i zniewala je swym widokiem. Lecz złoto, jeżeli obrabiasz je bardzo starannie, jest cenne na zewnątrz, ale wewnątrz jest tylko metalem" "79.

Odnosi biskup te słowa do religii pogańskiej, w której

„głoszą słowa wyszukane i wzniosłe, ale bronią rzeczy pozbawionych prawdy; mówią o Bogu, lecz adorują bożka"80.

Jasne jest więc, że mowa prawdziwego mędrca chrześcijańskiego powinna być całkowicie odwrotna - ma głosić słowami, ale przede wszystkim czynami, ma stosować język jasny i prosty, ale przede wszystkim umacniający i pouczający, ma mówić o Bogu i Jego prawdzie.

${ }^{78}$ Tamże, SAEMO 20, 24-26: ,alloquium tuum atque tractatus aliena non indigeat assertione; sed sermo tuus velut armis suis sese ipse tueatur nec ullum verbum tuum in vanum exeat et sine sensu prodeat. [...] Et ideo circa eos, qui gravi ulcere vexantur, utere oleo sermonis, quo foveas mentis duritiam: appone malagma, adiunge alligaturam salutaris praecepti, ut vagos et fluctuantes circa fidem vel disciplinae observantiam nequaquam soluto animo et remisso vigore patiaris perire", BOK 22, 9.

${ }^{79}$ Tamże 73, 2, SAEMO 21, 62: ,lingua sapientium litteratorum, quae faleratis dotata sermonibus et quodam splendentis eloquii velut coloris pretiosi corusco resultans capit animorum oculos specie formosa visuque perstringit. Sed aurum, si diligentius manu tractes, foris pretium, intus metallum est", BOK 28, 38-39.

${ }^{80}$ Tamże 73, 2, SAEMO 21, 62: ,pretiosa et grandia sonant, veri effeta defendunt; deum loquuntur, simulacrum adorant”, BOK 28, 39. 
Listy Ambrożego są wyjątkowym przykładem troski biskupa o duszpasterskie, społeczne i polityczne kwestie dotyczące miasta, diecezji, Imperium i Kościoła. Były one szczególnym sposobem pasterskiego oddziaływania biskupa Ambrożego. Zawarł w nich wiele wskazań moralnych, prawnych i dogmatycznych, pośród których ukazał też wzór mędrca chrześcijańskiego. Oparty on został na podstawach filozofii stoickiej, ale ostatecznie otrzymał chrześcijańską postać wynikającą z Pisma Świętego, a przede wszystkim z nauczania św. Pawła Apostoła. Według Ambrożego podstawową cechą mędrca jest wolność, ale posiada on również szereg innych cech - takich jak poddanie się Bogu, miłość wobec bliźnich, duch pokuty, znajomość Prawa Bożego - które konstytuują doskonałego mędrca, a ostatecznie doskonałego chrześcijanina.

\section{THE MODEL OF THE SAGE IN ST. AMBROSE'S LETTERS}

\section{(Summary)}

St. Ambrose's letters are a unique example of bishop's concern for pastoral, social and political issues relating to the city, the diocese, the Empire and the Church. They have been a special way of his pastoral influence and work. He included in them a number of moral, legal and dogmatic instructions, among which he described a model of the Christian sage. It was based on the statements of the Stoic philosophy, but finally the Christian character arising from Scripture, and especially from the teaching of St. Paul the Apostle, was added to Ambrose's model of a sage. According to Ambrose, the basic feature of the sage is freedom, but it also provides a number of other features - such as submission to God, love for the neighbours, the spirit of repentance, knowledge of God's Law - which constitute the perfect sage, and ultimately - the perfect Christian.

Key words: St. Ambrose of Milan, sage, wisdom, stoicism, letters, freedom, wealth, penance, epistolography.

Słowa kluczowe: Św. Ambroży z Mediolanu, mędrzec, mądrość, stoicyzm, listy, wolność, bogactwo, pokuta, epistolografia.

\section{BIBLIOGRAFIA}

\section{Źródła}

Ambrosius, Epistulae, SAEMO 19-21, ed. G. Banterle, Milano - Roma 1988, thum. P. Nowak: Św. Ambroży z Mediolanu, Listy, t. 1, BOK 9, Kraków 1997; t. 2, BOK 22, Kraków 2003; t. 3, BOK 28, Kraków 2012. 


\section{Opracowania}

Ammas J., The Sage in Ancient Philosophy, w: Anthropine Sophia. Volume in memory of Gabriele Giannantoni, ed. F. Alesse, Naples 2008, 11-27.

BobziEn S., Stoic conceptions of freedom and their relation to ethics, w: Aristotle and After, ed. R. Sorabji, Bulletin of Institute of Classical Studies, Suppl. 68, London 1997, 71-89.

Brouwer R., The Stoic Sage: The Early Stoics on Wisdom, Sagehood and Socrates, Cambridge 2014.

Kerferd G.B., The Sage in Hellenistic Philosophical Literature, w: The Sage in Israel and the Ancient Near East, red. J.G. Gammie - L.G. Perdue, Winona Lake 1990, 319-328.

Kerferd G.B., What Does the Wise Man Know?, w: The Stoics, ed. J.M. Rist, Berkeley Los Angeles - London 1978, 125-135.

McCabe M.M., The Stoic Sage in the Original Position, w: Politeia in Greek and Roman Philosophy, ed. V. Harte - M. Lane, Cambridge 2013, 251-274.

Naumowicz J., Wstęp, w: Św. Ambroży z Mediolanu, Listy, thum. P. Nowak, t. 1, BOK 9, Kraków 1997, 7-28.

Reale G., Historia filozofii starożytnej, tłum. E.I. Zieliński, t. 3: Systemy epoki hellenistycznej, Lublin 1999.

TATARKiewicz W., Historia filozofii, t. 1: Filozofia starożytna i średniowieczna, Warszawa 1993.

Wysocki M., Obraz chrześcijańskiego władcy w listach św. Ambrożego, VoxP 61 (2014) 171-177.

Wysocki M., Radości i troski biskupiego życia z perspektywy listów św. Ambrożego, Biskupa Mediolanu, w: Veritas Christi Liberat. Księga Pamiqtkowa ku czci Księdza Biskupa Jacka Jezierskiego w 65. rocznicę urodzin, 40. rocznicę kapłaństwa i 20. rocznice biskupstwa, red. K. Parzych-Blakiewicz - P. Rabczyński - J.M. Wojtkowski, Olsztyn 2014, 725-740. 